\title{
Identification of Anthrax in Endemic Areas in South Sulawesi Province
}

\author{
'Sartika Juwita, 'Purwanta, ${ }^{2}$ Muflihanah and ${ }^{3}$ Titis Furi Djatmikowati \\ 'Agricultural Extension College of Gowa, Indonesia \\ ${ }^{2}$ Molecular Laboratory of Disease Investigation Centre Maros, Indonesia \\ ${ }^{3}$ Bacteriology Laboratory of Disease Investigation Centre Maros, Indonesia \\ *Corresponding authors: Sartika Juwita (tika_drh@yahoo.co.id)
}

\begin{abstract}
Anthrax is a strategic and important disease because it is a zoonotic disease which caused death and difficult to eradicate because it produces spores. This study aims to identify the presence of anthrax in some of the endemic areas of the province of south Sulawesi, Indonesia. Soil samples obtained from Gowa and Pinrang regency were examined by bacterial culture test and then positive results from bacterial culture followed by multiplex PCR. Based on the results of the isolation of 52 soil samples show 35 samples of Pinrang regency are negative anthrax, while of 17 soil samples from Gowa regency, 2 indicate positive samples of anthrax. Positive samples of anthrax were from Timbuseng village, Patallasang district, Gowa regency. The results continued with $P C R$ technique using Bacillus anthracis colonies derived from positive soil samples. The test shows the virulent strain of Bacillus anthracis. A virulent strain is indicated by a DNA fragment of a pXO1 plasmid encoding a toxin lethal factor (Lef) of $385 \mathrm{bp}$ and a DNA fragment of a pXO2 plasmid encoding a capsule of anthrax (Cap) of $264 \mathrm{bp}$ and also common bacterial markers of the Bacillus genome chromosome (Ba183) of $152 \mathrm{bp}$. The conclusion of this study was Bacillus anthracis in Gowa regency is classified as a virulent strain.

Keywords: Bacillus anthracis, bacterial culture, pcr, soil sample, virulent strain
\end{abstract}

Copyright @ 2018 JRVI. All rights reserved.

\section{Introduction}

Anthrax is a strategic and important because it is a zoonotic disease causing death and is difficult to eradicate because its nature or producing spores. Anthrax is caused by Bacillus anthracis that can infect on different types of animals such as ruminant, horse, pig, deer, and rabbit. Moreover, anthrax can infect humans. In Indonesia, anthrax caused high mortality in cattle and causing economic losses were quite high. Losses estimated of approximately two billion rupiahs per year (Ditjen PKH, 2014; Aikembayev et al., 2010). Worldwide human anthrax cases were estimated at 2000 to 20,000 cases per year (Aikembayev et al., 2010).

There were several reports of cases of anthrax that occurred in Indonesia since the beginning of the incident until the events of 2004. The The First outbreak of anthrax in Indonesia was in 1932 in Tirawuta and Mowewe district of Southeast Sulawesi. In 2000 in Purwakarta region, anthrax caused high mortality of ostriches and also attacked 32 people clinically. In 2001, the incidence of anthrax appeared in Hambalang Bogor in West Java attacking goats and sheep and caused 2 deaths whereas 22 people show clinical symptoms. In 2002, in Bogor anthrax attacked goats and sheep causing 6 deaths to humans. In 2004, in Bogor anthrax appeared on goats and sheep as well as caused 6 deaths to humans. From 1999 to 2004 it was reported that there were 599 human cases of anthrax of which 22 people have died (Wahyuni, 2004). 
The incidence of anthrax in Indonesia is often repeated and become great problems. Some technical issues behind of anthrax epidemic are low vaccination coverage in an infected village, vaccination program are not optimal, lack understanding about epidemiology, low public awareness of anthrax, and there is a problem in anthrax vaccination in cattle. The problems affect the control and eradication of anthrax. One of the factors that could cause the failure of vaccination is the vaccine is derived from a strain that is not protective (Akoso, 2009). Others issues include improper application of the vaccine, insufficient dose, the low quality of the immunogenic of the vaccines seed as well as the individual responses of cattle (OIE, 2000). As a consequence, the incidence of anthrax can recur.

The incidence of anthrax disease in endemic areas in South Sulawesi Province is still recurrent (CIVAS, 2014). The pattern of the spread of anthrax in South Sulawesi province from 2010 to 2014 tends to recur and spreading making the possibility newly infected areas is widely open (Dariana et al., 2015). The multiplex PCR technique is able to detect and identify the presence of the Bacillus anthracis isolated from active soil surveillance samples in the field as well as the rapid and accurate detection of Bacillus anthracis from blood samples (Wibawa et al., 2014). Based on the problems, researchers interested in conducting research related to the identification of anthrax in endemic areas in South Sulawesi Province.

\section{Materials and Methods}

\section{Samples}

The research was conducted in cattle farms owned by the people from Gowa regency and Pinrang regency for sample selection and Disease Investigation Centre of Maros for staining and culture of Bacillus anthracis as well as multiplex PCR. Soil samples were taken from filed in Gowa Regency and Pinrang Regency. The number of samples are 52 consisting of 17 gowa samples and 35 samples from Pinrang. Soil sampling was conducted randomly based on the historical location of cattle mortality due to anthrax disease. The soil samples were taken in the morning with a depth of $15 \mathrm{~cm}$ above ground level.

\section{Culture Method}

25 grams soil samples were mixed with $100 \mathrm{ml}$ physiological saline sterile in a sealed tube and shake for 2 hours then incubated at room temperature for one night. After that, $7 \mathrm{ml}$ of the supernatant is taken carefully and is inserted into a sterile tube before heated in a water bath with a temperature $62,5^{\circ} \mathrm{C}$ for $15-30$ minutes and centrifuged at $3000 \mathrm{rpm}$ for 15 minutes. Supernatant is carefully discarded in a safe place. The suspension is then cultured in $5 \%$ sheep blood agar medium and incubated at $37^{\circ} \mathrm{C}$ for 24 hours. Then, observed morphologically. The technique staining of testing Bacillus anthracis uses fast polychrome staining of $1 \%$ methylene blue (Departemen Pertanian, 1999).

\section{Multiplex PCR Technique}

DNA extraction is using Pure Link Genomic DNA Kit (Invitrogen, catalog no. K1820-01). The process combines $180 \mathrm{~mL}$ of Genomic Digestion Buffer to $25 \mathrm{~mL}$ and $200 \mathrm{~mL}$ Proteinase K specimens. The suspension is placed on a vortex and incubated at $55^{\circ} \mathrm{C}$ for 15 minutes. Then the suspension is centrifuged at maximum speed for 3 minutes. Afterwards, it was added with $20 \mathrm{~mL}$ of RNase and sentback at the incubated at room temperature for 2 minutes. The suspension is then transferred to a new tube and added $200 \mathrm{~mL}$ of Genomic Lysis / Binding 
buffer and placed on a vortex. A $200 \mathrm{~mL}$ of absolute ethanol is added, and the tube is placed again on a vortex and centrifuged.

The suspension was transferred to Qiamp Spin Column. Then, centrifuged for 5-10 minutes at a speed of $12000 \mathrm{rpm}$, all the liquid being stored in the Collection Tube discarded. It then was added with $500 \mathrm{~mL}$ of Wash Buffer 1 to wash the spin column membrane, and then re centrifuged for 5-10 minutes at a speed of $8000 \mathrm{rpm}$. All of the liquid being stored in the Collection tube is removed, then added $500 \mathrm{~mL}$ of Wash Buffer 2 to wash the spin column membrane, and then re-centrifuged for 15 minutes at a speed of $8000 \mathrm{rpm}$. Then the supernatant is removed and centrifuged again for 1 minute at a speed of $8000 \mathrm{rpm}$ (without fluids). Then replaced recovery collection tube with $1.5 \mathrm{ml}$ tube and added $50-100 \mathrm{~mL}$ of Genomic elution buffer and allowed to stand at room temperature for 1 minute. Suspension back centrifuged at a speed of $12000 \mathrm{rpm}$ for 3 minutes. Qiamp disposed Spin Column and collection tube labeled. Eluted liquid is total DNA to be stored at $-80^{\circ} \mathrm{C}$. Primer used are PXO1 - toxin genes (lef-3 : 5' CTT TTC CAT ATT ATA TCG ACC-3' and lef-4 : 5' GAA TCA CGA ATA TCA ATT TCT AGC-3'), PXO2 -capsule genes (Cap-57 : 5' ACT CGT TTT TAA TCA GCC CG-3' and Cap-58 : 5'CGT AAC CCT TCT CTT TCA AT-3'), and Chromosomal markers (Ba813R1: 5'TTA ATT CAC TTG CAA CTG ATC GG-3' and Ba813R2 : 5' AAC GAT ACC TCC TAC ATT TCG AG-3') (9). Making TBE $10 \%$ (in volume $500 \mathrm{~mL}$ ) was by adding $10 \times$ TBE 50 $\mathrm{mL}$ to $450 \mathrm{~mL}$ in sterile distilled water in order to obtain a total volume of $500 \mathrm{~mL}$. The solution is thoroughly mixed. Making the $2 \%$ agarose gel by weighing the agarose according to the desired volume, then the solution TBE agarose heated together to boiling and a solution looks clear. Ethidium bromide was added as much as $2-5 \mathrm{~mL}$ or can also with SYBRR Safe DNA gel stain (Cat. No. S33102). Next, Agarose poured into the mold and wait until it hardens. Once hardened inserted into the electrophoresis chamber. TBE $1 \mathrm{X}$ solution was added to agarose submerged completely. Samples were inserted coupled with loading dye 1.5 - $2 \mathrm{~mL}$ into each well. Each test was always included DNA electrophoresis ladder (commonly used 100 bp DNA ladder). Agarose and running sample used 90 volt power supply, $400 \mathrm{~A}$ for 90 minutes. Then the reading of the results was done by UV illuminator Viewer or Gel Doc System (Bio Rad) (Hornitzky et al., 2010).

\section{Results and Discussion}

The results of the isolation of 52 soil samples showed 35 samples from Pinrang Regency show all negative anthrax, while of 17 soil samples from Gowa Regency, 2 show positive samples of anthrax. Positive samples of anthrax are from Timbuseng Village, Patallasang District, Gowa Regency. Factor that influence all soil samples from Pinrang regency found negative because the land is estimated to have been buried or carried away by the flow of rainwater (Barkah, 2001). Anthrax cases in Gowa regency was reported in 2010, 2014, 2015 and 2016, whereas in Pinrang regency cases of anthrax was reported in 2016 (Ditjen PKH, 2016).

Factors contributing to the incidence of anthrax cases in Gowa regency are the difficulty of eradicating anthrax caused by anthrax bacteria in the form of spores. Anthrax spores have the ability to survive for very long periods even under certain conditions can survive decades into soil (Ditjen PKH, 2014) as well as factors related to the season, such as available grazing, the health of the host, insect populations and human activities (WHO, 2008).

Bacillus anthracis colonies found are rough shape, flat, gray, non-hemolytic and the edges are uneven and at low magnification identical to hair straggling. Bacillus anthracis grows at a temperature of $37^{\circ} \mathrm{C}$ for $18-72$ hours. The characteristics of the Bacillus anthracis colonies are mucoid colonies that are smooth due to the substance produced by the Bacillus anthracis 
capsule (Todar, 2014). The presence of a capsule indicates Bacillus anthracis is not a result of fertilization in artificial media repeatedly (11) (Figure 1)

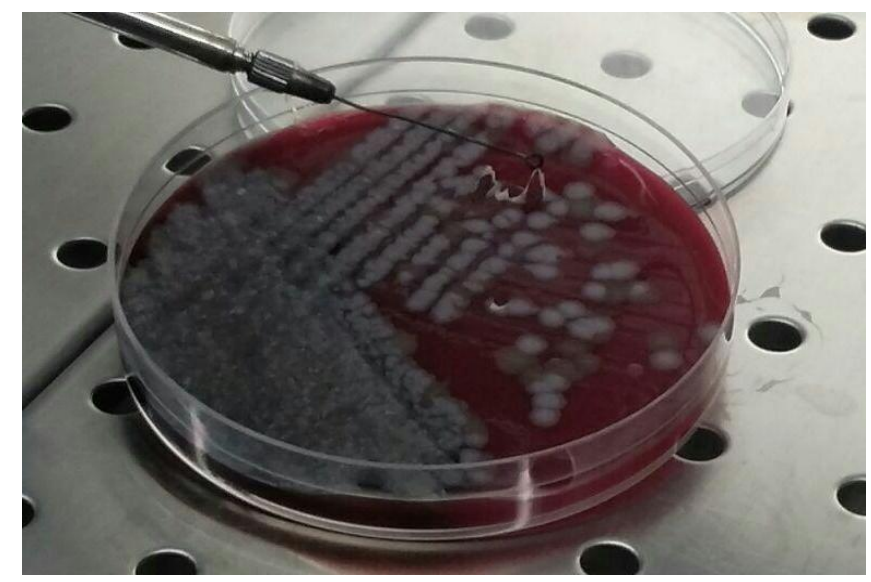

Figure 1. Bacillus anthracis colonies on sheep blood agar medium

The results is continued to be examined with PCR technique using Bacillus anthracis colonies derived from positive soil samples. It showed the virulent strain of Bacillus anthracis. Virulent strain is indicated by a DNA fragment of a pXO1 plasmid encoding a toxin lethal factor (Lef) of $385 \mathrm{bp}$ and a DNA fragment of a pXO2 plasmid encoding a capsule of anthrax (Cap) of $264 \mathrm{bp}$ and also common bacterial markers of the Bacillus genome chromosome (Ba183) of 152 bp (Figure 2).

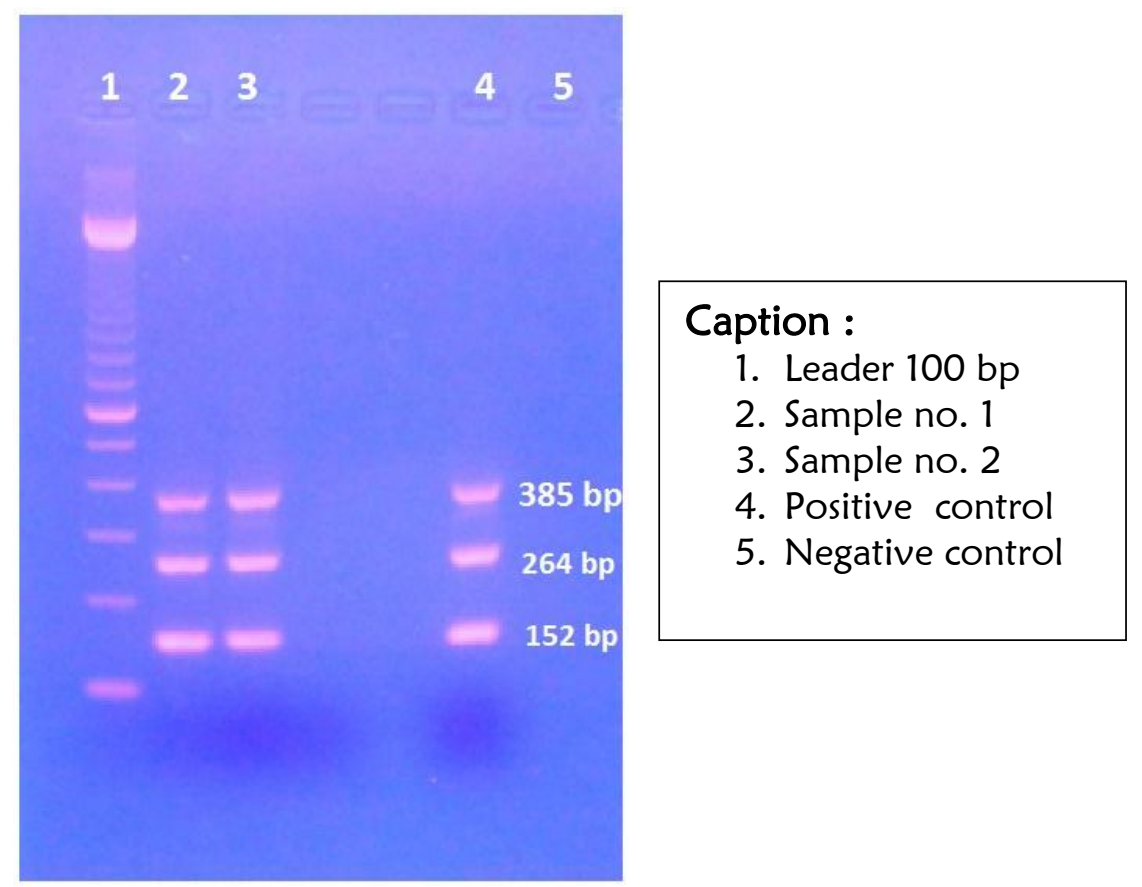

Figure 2. Results of Multiplex PCR from positive samples culture

The data of 2011 - 2014 period indicates that the anthrax case in Timbuseng village is a new case. Based on the same duration, the spread of anthrax incidents in Gowa regency deems to be expanding, from initially attacking one village only in Bajeng sub-district to attacking in 10 villages in 6 different sub-districts (Dariana et al., 2015). Studies also show that endemic areas (with a history of anthrax) have a recurrent pattern of occurrence and the location of the 
endemic is also likely to extend from year to year by the increasing number of location of villages, sub-districts, and regency from year to year. As a case in point, in 2016, the incident of anthrax was found in Pinrang regency where anthrax case had never been previously found. Kholilullah et al. (2016) reports that Sidrap regency and Maros regency are also positive for Baccilus anthracis. It is believed that endemics in these areas are mainly caused by the lacking of vaccination coverage. Control and prevention of anthrax in endemic areas is done by vaccination using active vaccine (Adji et al., 2006). PCR results using Bacillus anthracis colonies derived from positive soil samples, showed that the identified virulence strain of Bacillus anthracis.

The identification of a virulent strain using a Bacillus anthracis colony derived from a positive soil sample showed a virulent strain of Bacillus anthracis. The virulence and pathogenicity of Bacillus anthracis is determined by molecular determinants such as poly-D-glutamyl capsule synthesized by plasmid pXO2 and plays a role in the invasive phase of Bacillus anthracis infection and multicomponent of anthrax toxin that is protective antigen (PA), lethal factor (LF) and edema factor (EF) produced by plasmid pXO1 and contribute to bacterial toxigenic stage (Todar, 2014; Hanna et al., 1999; Hicks et al., 2011; Liu et al., 2014). All of the Bacillus anthracis virulent strains have capsules in which the production of these capsule materials is associated with specific mucus formation in the fine colonies of virulent anthrax bacteria. Virulence is strongly related or influenced by synergies and combinations of activity of each factor/toxin, where each toxin has no deadly effect on the host's body if it works independently. For examples, combinations of PA + LF toxins produce lethal activity, EF + PA produces edema, PA + LF + EF produces lethal edema and necrosis (Todar, 2014).

\section{Conclusion}

Bacillus anthracis in Gowa regency is classified as a virulent strain. A virulent strain is indicated by a DNA fragment of a pXO1 plasmid encoding a toxin lethal factor (Lef) of $385 \mathrm{bp}$ and a DNA fragment of a pXO2 plasmid encoding a capsule of anthrax (Cap) of 264 bp and also common bacterial markers of the Bacillus genome chromosome (Ba183) of $152 \mathrm{bp}$.

\section{Acknowledgment}

This research was made possible by grant from Agricultural Extension College of Gowa. The authors state there is no conflict of interest with the parties concerned in this research.

\section{References}

Aikembayev, AM., Larissa, L., Gulnara, T., Tatyana, MM., Yerlan, P., Sarkis, Z., Georgiy, DW., Ryan, E., Matthew, NVE., Paul, K., Stephen, CF., Jason, KB., Martin, HJ., and Ted, H. 2010. Historical distribution and molecular diversity of Bacillus anthracis Kazakhstan. Emerging Infectious Disease 16(5) : 789-796.

Adji, RS., dan Natalia. 2006. Pengendalian penyakit antraks: diagnosis, vaksinasi dan investigasi. Wartazoa 16(4): 198-205.

Akoso, BT. 2009. Epidemiologi dan pengendalian antraks. Penerbit Kanisius. Yogyakarta

Barkah, K. 2001. Isolasi Bacillus anthracis pada kasus anthrax di Bogor. Temu teknis fungsional non peneliti : 176 - 183.

CIVAS. 2014. Antraks. Centre for Indonesian Veterinary Analytical Studies.

Dariana, W., Djatmikowati, TF., dan Poermadjaja, B. 2015. Distribusi anthraks di Sulawesi Selatan Periode 2010-2014. Prosiding Penyidikan Penyakit Hewan Vo.1 No.6.

Ditjen PKH. 2016. Pedoman pengendalian dan pemberantasan penyakit hewan menular seri penyakit Anthrax, Kementerian Pertanian. 
Ditjen PKH. 2014. Manual penyakit hewan mamalia cetakan ke-2. Subdit Pengamatan Penyakit Hewan hal 119 - 132. Kementerian Pertanian.

Departemen Pertanian. 1999. Manual standar metode diagnosa laboratorium kesehatan hewan. Direktorat Jenderal Peternakan, Departemen Pertanian

Hanna, PC., and Ireland, JA. 1999. Understanding Bacillus anthracis pathogenesis. Trends Microbil 7(5):180-182.

Hicks, CW., Cui, X., Sweeney, D.A., Li, Y., Barochia, A., and Eichacher, PQ. 2011. The Potential contributions of lethal and edema toxins to the pathogenesis of anthrax associated shock. Toxins (Basel) 3 (9): 185-202.

Hornitzky, MA., and JD Muller. 2010. Anthrax. Australia and New Zealand standard diagnostic procedure 1-15.

Kholilullah, ZA., Massi, MN., Muslimin, L., Sjahril, R., Hamid, F., and Wahid, I. 2016. Identification of virulence of Bacillus anthracis from soil by multiplex PCR technique in the South Sulawesi Province of Indonesia. American Journal of Infectious Disease and Microbiology 4(6): 118-122.

Liu, S., Moayeri, M., and Leppla, SH. 2014. Anthrax lethal and edema toxins in anthrax pathogenesis. Trends Microbiol 22(6): 317-325.

OIE. 2000. Antraks. In: Manual of standards diagnostic and vaccines, World Health Organization

Todar, K. 2014. Bacillus anthracis and Anthrax: In Todar's Online Texkbook of Bacteriology

Wahyuni. 2004. Tinjauan hasil vaksinasi antraks pada sapi dan kambing-domba di Indonesia. Lokakarya Nasional Penyakit Zoonosis.

WHO. 2008. Anthrax in humans and animals fourth edition. WHO library cataloguing in publication data.

Wibawa, H., Sudarsono, I., Pramastuti, I., dan Handoko, A. 2014. Deteksi dan identifikasi agen penyakit anthrax dengan teknik multiplex polymerase chain reaction. Buletin laboratorium veteriner Vol.14: No.3. 